\title{
高度安全病室 $\mathrm{X}$ 線撮影における FPD 遠隔操作システムの構築 飯塚 明寿 ${ }^{1)} \cdot$ 山内 $\quad$ 真澄 ${ }^{2.3)} \cdot$ 深川 敬子 ${ }^{2,3)} \cdot$ 倭 正也 ${ }^{2,34}$
}

\section{Implementation of a Remotely Controlled FPD System for X-ray Imaging in an Advanced Isolation Room}

\author{
Akihisa IIZUKA ${ }^{1)}$, Masumi YAMAUCHI ${ }^{2,3)}$, Keiko FUKAGAWA ${ }^{2,3)}$ and Masaya YAMATO $\left.2,3,4\right)$
}

\begin{abstract}
${ }^{1)}$ Department of Radiology, Rinku General Medical Center, ${ }^{2)}$ Department of Infection Control Management, Rinku General Medical Center, ${ }^{3)}$ Rinku General Medical Center, Center for Infectious Diseases, ${ }^{4)}$ Rinku General Medical Center Division of General Medicine and Infectious Diseases
\end{abstract}

(2019 年 9 月 17 日受付 $\cdot 2019$ 年 11 月 14 日受理)

要旨

特定感染症指定医療機関に指定された当院は, 2014 年に西アフリカで大流行したエボラ出血熱 への対応の一環として同年 10 月にポータブル撮影対応 flat panel Detector システム（FPD システ ム) を導入した. その直後にエボラ出血熱疑いの患者受け入れがあり, 高度安全病室内において FPD システムを用いた X 線撮影を実施した。 その経験からエボラ出血熱患者の X 線撮影では早期画像 観察および診断と感染拡散防止の観点でFPD システムが非常に有用であった。そして, さらに高 度安全病室内での FPD システムの操作をさらに軽減するために FPD 遠隔操作システムの構築を 行った. FPD 遠隔操作システムの原理は今後の高度安全病室内での医療機器の操作において感染 制御の観点で有用である。

Key words : 特定感染症指定医療機関, 高度安全病室, X 線撮影, flat panel detector 遠隔操作シ ステム

序文

当院は特定感染症指定医療機関に指定された感染症セ ンターを有している. その感染症センターの 7 床のうち 2 床が高度安全病室で未知の感染症に対応可能な病室で ある。その病床において, 2003 年に重症急性呼吸器症 候群 ${ }^{1)}$ (Severe acute respiratory syndrome (SARS)) 疑いの患者受け入れを行った経験があった。

2014 年に西アフリカでエボラ出血熱がアウトブレイ クし 2015 年 5 月までに 1 万人以上が死亡した ${ }^{2,3)}$.この 状況下で, エボラ出血熱の国内流入を未然に防ぐ対策が 早急に必要となった。

当院は関西空港の対岸に位置するため, 関西空港検疫 所からのエボラ出血熱を含めた輸入感染症を疑う患者の

1) りんくう総合医療センター放射線技術科, 2)りんくう総合医療セ ンター院内感染対策室, 3)りんくう総合医療センター感染症セン 夕ー, 4) りんくう総合医療センター総合内科・感染症内科
受け入れ要請対象施設になっている. そのため当院では エボラ出血熱患者受け入れ対策を, 感染症センターが中 心となり行った。その一環として, 2014 年 10 月に感染 症センター内での X 線撮影にポータブル撮影対応 flat panel Detector システム（FPD システム）を導入した.

我々は, その直後の 2014 年 11 月にエボラ出血熱疑い 事例の受け入れを経験した。 その際に患者は感染症セン ター内の高度安全病室に入室し, 直後に診断および治療 方針の決定を目的とし病室内において FPD システムに て胸部 X 線撮影を行った。

この症例を通じて, 早期画像診断と感染拡散防止の観 点で, 高度安全病室内でのエボラ出血熱疑い事例に対す るX線撮影において, FPD システムと旧システムであ る computed radiography システム（CR システム）を 比較し FPD システムの有用性についての検討を行った. なお, 高度安全病室内での CR システムは 2003 年の SARS の受け入れ時に使用している. その際には高度安 


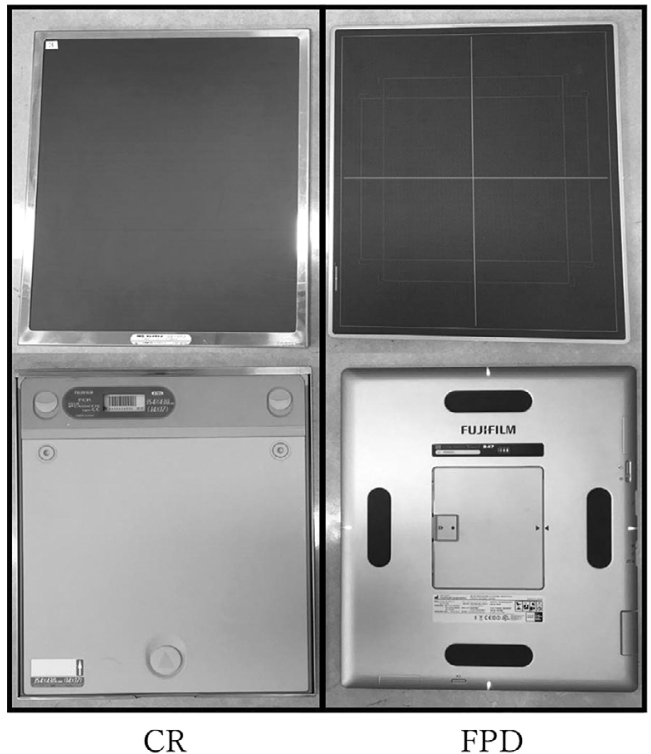

図 $1 \mathrm{CR}$ と FPD の比較（外観）

全病室外へ $\mathrm{CR}$ を持ち出す必要があり, その際の感染防 御に細心の注意と労力を必要とした.

また, FPD システムにおける personal computer (PC) 操作が Full Personal protective equipment (PPE) 時 には非常に困難で煩雑であるとの指摘を受けていた。 そ の操作負担を軽減する方法として, 污染区域外の別室に て FPD システムの PC を操作する FPD 遠隔操作システ ムを構築したた。

さらにその後に, 感染症センター内の高度安全病室に おいて 2015 年 9 月に中東呼吸器症候群 (Middle East Respiratory Syndrome（MERS)）疑い, 2018 年 8 月に 鳥インフルエンザ疑いの患者受け入れを行った。両者と も初期段階で診断㧍よび治療方針の決定のために, 高度 安全病室内に扔いて当該患者の胸部 X 線撮影を FPD 遠 隔操作システムにて行った.

当論文は高度安全病室におけるX線撮影方法の変遷 とその有用性を踏まえ, FPD 遠隔操作システムの構築 について報告する.

\section{対象システムと方法}

\section{対象システム}

今回の検討対象の CR と FPD を図 1 に示す。両者と も FUJIFILM 社製である.FPDに関しては, 防水機能 を有した Irradiation Side Sampling (ISS) 方式による 間接変換方式 $\mathrm{FPD}^{4)}$ である.

また， CR システムは CR のほかに CR 読み取り装置, 通信及び画像操作を行う PC, 画像観察モニター（図 2) が含まれる，FPD システムはFPDのほかに FPD 通信 及び画像操作を行う Windows ベースで動作するモバイ ルノート PC（図3）が含まれる.

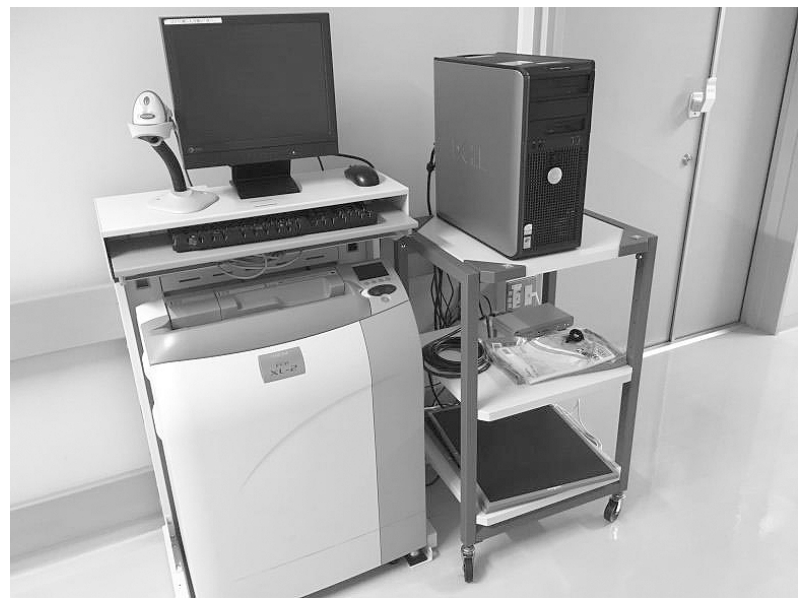

目 2 CR システム

\section{方 法}

1. CR システムと FPD システムの比較

当院に扔ける 2003 年の SARS 疑い事例受け入れ時の CR システムと 2014 年のエボラ出血熱疑い事例, 2015 年の MERS 疑い事例受け入れ時の FPD システムを早期 画像診断と感染拡散防止の観点から比較検討を行った.

\section{FPD 遠隔操作システム}

FPD システムの PC と感染症センターナース ステー ションのPCを院内イントラにて接続し, FPD システ ムの PCにフリーソフトの Ultra VNC Ver. 1.2.2 を, 遠 隔操作を行う PC にフリーソフトの VNC VIEWER Ver. 6.0.2を用いて遠隔操作環境を構築した（FPD 遠隔操作 システム)。そして, エボラ出血熱・MERS 等の患者搬 送訓練や 2018 年の鳥インフルエンザ疑い事例, 2018 年 の MERS 疑い事例受け入れ時にその有用性を検証した.

さらに, FPD システムの PC は遠隔で操作するため にX線機器に設置する必要がない。 それ故に PC は污 染の危険が低い場所に設置し, 映像は PC の外部出力に て高度安全病室の大型モニターに映し出した。

\section{結 果}

1. $\mathrm{CR}$ システムと FPD システムの比較 早期画像診断

FPD システムで撮影された代表画像として MERS 疑 い患者の X 線画像を図 4 に示す（揭載に関し該当患者 同意済み)。画像において障害院影はなく肺炎の有無や 心陰影の確認は十分にできる画像である.

また，FPD システムでは X 線撮影後に高度安全病室 内で FPD システム上の PCでほほ同時に撮影された画 像の観察ができた。

それに対し, $\mathrm{CR}$ システムでは $\mathrm{X}$ 線撮影後に撮影のた めに患者背面に設置された $\mathrm{CR}$ を取り出し, 別室にある 読み取り装置までの搬送が必要である。ささらに， CR 読 み取り装置による読み取り処理が必要なため画像の観察 


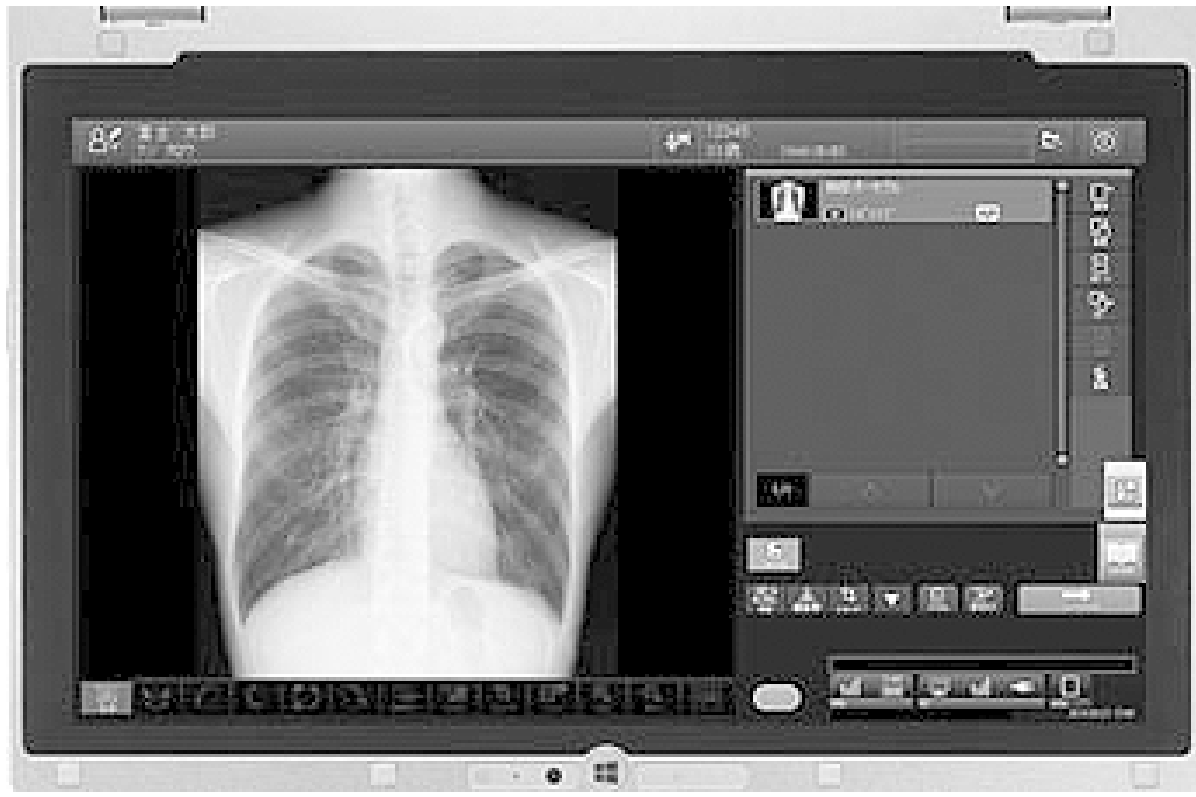

図 3 FPD システム（モバイルノートPC）

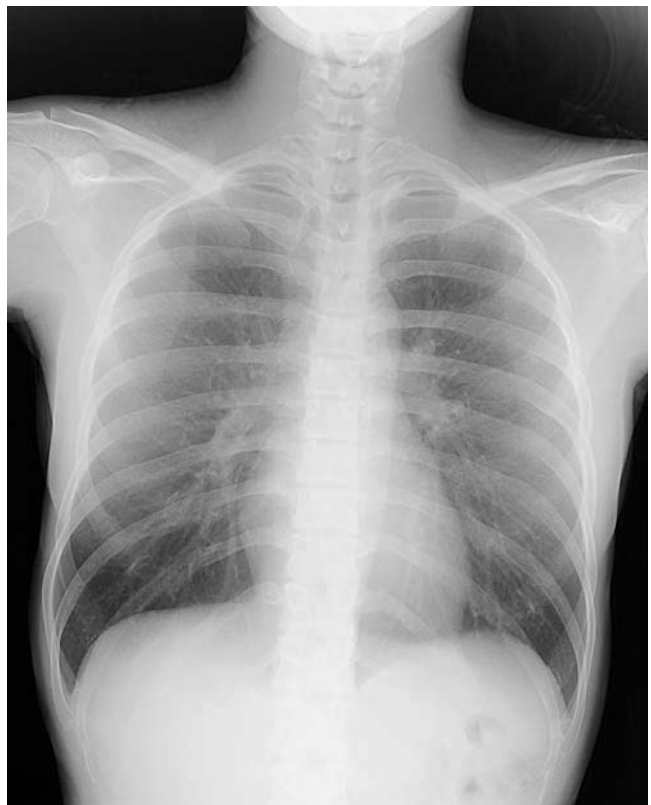

図 4 FPD システムで撮影された MERS 疑い患者の X 線画像

\section{を行うには数分の時間が必要であった.}

感染拡散防止

FPD システムでは患者に触れた FPD を高度安全病室 外に出す必要が無いため感染拡散防止対策は不要であっ た. CR システムでは CR の高度安全病室外への移動が 生じる. その際に患者に触れる $\mathrm{CR}$ に対する感染拡散防 止策としてビニール袋による梱包が必要であった。

また, 続けて撮影が必要な場合, CR システムでは再 度患者の背面に CR を設置することから行わなければな らない. しかしながら, FPD システムでは FPD は患者
の背面に設置されたままであるので, 患者背面での FPD の上下もしくは左右の移動のみである. そのため患者と の接触時間は $\mathrm{CR}$ システムに比べ少なくなった.

さらに，本法における FPD は防水であるのでそのま ま消毒液につけることが可能であった。しかし，CR は 防水ではないため相包等の感染拡散防止策以外に次亜塩 素酸（HClO）を主成分とする環境除菌クロスでの拭き 上げを行う必要があった。

\section{FPD 遠隔操作システム}

本法では FPD システム操作は全て遠隔で行うため, 医師が X 線曝射を医師やその他に医療スタッフが flat panelの設置のみを行うだけとなり，その他の放射線機 器関連の操作は不要となった。 また, 画像観察が大型モ ニターで行えるため通常の 12 インチの FPD システム の $\mathrm{PC}$ に比べ視認性が上昇した.

エボラ出血熱・MERS 等の患者搬送訓練や鳥インフ ルエンザ疑い患者対応時において，本法における不具合 は全くなかった。

\section{考察}

今回のエボラ出血熱疑い事例は, Polymerase Chain Reaction (PCR) 検査 ${ }^{5,6)}$ の結果エボラ出血熱陰性であっ た.しかしながら，PCRの結果が判明するまでの間は エボラ出血熱陽性患者として現場では対応しており, 今 回の検討及び考察は, エボラ出血熱患者の対応と同等に 扱えるものである。 それゆえに以下の考察はエボラ出血 熱患者の対応として行う. MERS 疑い事例, 鳥インフ ルエンザ疑い事例も同様に疑いであるが上記理由より同 様に扱う。 
今回は早期画像診断と感染拡散防止の観点から CR シ ステムと FPD システムの比較検討を行った. FPD はそ れ以外にも CR に比べて軽量である. CR が $3.1 \mathrm{Kg}$ (グ リッド含む) に対し FPD は $2.6 \mathrm{Kg}$ である。しかしなが ら，FPD はそれ自体が精密機器であるため衝撃に対し て弱く取り扱いには注意が必要である。 それに比べ CR はシンプルな構造であるため取り扱いは容易である.こ の点は CR システムが FPD システムより優れている.

FPD システムはX 線撮影とほぼ同時に高度安全病室 内において FPD システム上の PCで画像確認及び画像 診断ができる。これは FPD システムが CR システムよ り最も優れている点である. 従来の CR システムでは正 しい撮影が行われたかの確認も別室にCR を運び, 読み 取り処理を行いその後に初めて画像確認をすることがで きる. 画像に不具合があり, 再撮影が必要な場合は, 再 度患者の背面に CR を設置することから始める必要があ り，感染曝露のリスクが上昇する，FPD システムでは その場で画像の不具合を確認し, 再撮影が必要な場合は, FPD の位置を若干変えることで対応できる. FPD シス テムは $\mathrm{CR}$ システムのように撮影ごとにカセッテを入れ 替える必要がないため, 再撮影時や追加撮影において患 者との接触を格段に減らすことができ, 感染曝露のリス ク上昇は CR システムに比べ少ない.

FPD システムで画像観察が瞬時にできることは当然 迅速な診断に寄与できると同時に早期の治療開始に貢献 ができる。ささらに画像の拡大やコントラストの変更と いった画像操作も高度安全病室内の FPD システム上の $\mathrm{PC}$ で行うことができる. CR システムは読み取り装置 まで CR を運搬する必要がある。これは患者に触れた感 染媒体を高度安全病室外に出す行為である。この際の感 染対策には細心の注意を払う必要があるのは当然であり 神経を使う場面である。

反対に FPD システムはFPDを高度安全病室外に出 す必要がない. 長時間の使用の際はFPD P FPD シス テム上の $\mathrm{PC}$ の充電が必要になるが, 充電装置は大きな ものではないため高度安全病室内に設置可能である. 感 染媒体を病室外に持ち出す必要がないため, CR システ ムに比べ感染媒体を減らすことができる.これは, カセッ テの感染対策に神経を使っていたドイツの T. J. Vogl ら のエボラ出血熱症例報告 ${ }^{7)}$ と比較しても優位である.こ れらの FPD システムと CR システムの差を少なくする には, CR システムのすべてを高度安全病室内に持ち込 めば感染対策においての差はなくなるが, CR の読み取 りにかかる時間の差は埋めることはできない.ただし, CR システムのすべてを高度安全病室内に持ち込むには 作業スペースを含め病室ベッド相当の床占有面積が必要 である。

FPD システムにおいて今回の FPD 遠隔操作システム
導入前の経験で唯一の問題点が, full PPE を装着した状 態で FPD システムのモバイル PC 操作を行わなければ ならない点であった， CR システムでは CR の読み取り 処理や画像処理は高度安全病室外の管理区域外で行うた め, 操作時に PPE は不要である. 反対にエボラ出血熱 患者の病室内では，患者対応を含めすべての作業は Full PPEを装着した状態で行われる ${ }^{8,9)}$. PPEでの作業は当 然ながら通常作業に比べ，かなりの自由を奪われ困難な 作業となる. 今回の FPD 遠隔操作システムはこの問題 点の解決手法として構築した. さらに, 遠隔操作では $\mathrm{PC}$ をモバイル機として使わないため, コンセントに常につ ないだ状態で使用できる，そのため先に述べた FPD シ ステム上の $\mathrm{PC}$ の充電の問題は解決される.

今回遠隔操作の対象装置の PC は Windows ベース動 作しているため, 市場に出回る遠隔通信に関するソフト ウエアが利用可能である。 その遠隔操作法として使用す るソフトウエアは，今回利用したVNC VIEWERをは じめ多く存在する。これらのソフトウエアを大別すると ウェブブラウザを使用するか否かで分けられる. ウェブ ブラウザを使用するソフトウエアとしてはTeamViewer 等が，ウェブブラウザを用いないものとしては 今回使用したVNC VIEWERがある。今回ソフトウエ アの採択条件は，動作が軽いことを第一に考えた．加え て院内のみの運用であるためウェブブラウザを用いる必 要が全くないことから VNC VIEWER Ver. 6.0.2 を使用 した.

今回のシステムの動作環境は FPD システムの PC の 動作環境に依存する。そのため遠隔操作に用いる $\mathrm{PC}$ は 高性能である必要はなくVNC VIEWER が動作し, ネッ トワーク上で閲覧ができれば問題がない。事実当院はシ ングルコアの Intel Celeron $530(1.73 \mathrm{GHz})$ 搭載の PC で行っている.

今回の遠隔操作構築では院内ネットワークに FPD シ ステムと通信可能な環境がすでにあれば，VNC 関連ソ フトはフリーソフトであるため新たに必要な費用はこの $\mathrm{PC}$ のである. $\mathrm{PC}$ は数年前の低スペックなものでも 使用できるため初期費用は抑えられる。この遠隔操作の 原理はWindows ベースの PCで動作するすべての医療 機器に応用可能であり, 院内の電子カルテ等も動作させ ることができ，今回のように室内のモニターに様々な情 報を映し出すことが可能である。 また，大型の室内モ二 ターを使用することで医療機器に設置された PC 等のモ ニターよりも視認性を上昇させることが可能である.

高度安全病室内との音声通信環境が整った部屋の医療 スタッフとの間の連携で, 高度安全病室内での医療機器 操作に費やす作業量を大きく減らすことができる．これ は滞在時間が限られる高度安全病室内において患者に費 やせる時間が増加することになる，病室外の医療スタッ 
フが遠隔操作を通じて病室内での作業ができることは, 病室内にもう一人医療スタッフがいることとほぼ同等で ある。高度安全病室内の限られた空間内に一人医療又 タッフが入室することで, その作業スペースは確実に減 ると同時に安全性も低下する．室内空間を占拠すること のない遠隔操作はその観点で優れている.

$\mathrm{FPD}$ 遠隔操作システムは FPD システムの PCに一切 触れないため, PC を媒体とする感染の制御が容易にな る。また, 感染患者を前にした病室内医療スタッフの緊 張の高さは容易に想像ができる。この状況下において煩 雑な FPD システム操作はさらに緊張と不安が増強され ると考えられる。 FPD 遠隔操作システムでは，これら のストレスが当然軽減される。これは医療安全の観点か らも非常に有用であると考える. さらに, 病室外で遠隔 操作を行う医療スタッフは，当然ではあるが日常と何ら 変わりない空間で作業ができる。この環境は多くのス タッフが同時に携わることが可能であると同時に患者か らの感染曝露がない

今回構築を行った高度安全病室 X線撮影における FPD 遠隔操作システムは，X 線撮影装置にとどまるこ となく, Windows ベース動作しているネットワーク機 能を有する多くの医療機器を遠隔操作できる可能性が示 唆される。 これは, 煩雑な医療機器の操作を感染曝露と いう緊張状態のない状況下で行えることとなり非常に有 用である。
利益相反自己申告：申告すべきものなし

文献

1）松山州徳：中東呼吸器症候群（MERS）コロナウイルス感 染症. 獸医疫学雑誌 2013; 17(2): 112-6.

2）国立感染症研究所：エボラ出血熱とは：http://www.nih.go $\mathrm{jp} / \mathrm{niid} / \mathrm{ja} / \mathrm{ebola} / 4925$-ebola-top.html.

3）川名明彦, 尾家重治, 加來浩器, 加藤康幸, 黒須一見, 中 島一敏, 他 : エボラ出血熱関連情報資料集 Vol\#1（2015 年 5 月 18 日版), 日本環境感染学会.

4）佐藤圭一郎, 成行書史, 桑原 健, 福井真一郎, 岡田美広, 鍋田敏之, 他：高変換効率の間接変換型デジタルラジオグ ラフシステム「CALNEO」の開発. FUJIFUILM RESEARCH \& DEVELOPMENT 2010; 55: 10-3.

5) Ksiazek TG, Rollin PE, Williams AJ, Bressler DS, Martin ML, et al: Clinical virology of Ebola hemorrhagic fever (EHF): virus, virus antigen, and IgG and IgM antibody findings among EHF patients in Kikwit, Democratic Republic of the Congo, 1995. J Infect Dis 1999; 179 Suppl 1: S177-87.

6）エボラ出血熱診断マニュアル一厚生労働省一戸山研究庁 舎 : https://www.niid.go.jp/niid/images/lab-manual/ebora 2012.pdf.

7) Vogl TJ, Martin S, Brodt HR, Keppler O, Zacharowski K, Wolf T: The Frankfurt Ebola Patient Der Frankfurter Ebola-Patient. Fortschr Röntgenstr 2015; 187: 771-6.

8) Donning Biological PPE - Ebola Patients, Doffing Biological PPE - Ebola Patients, University of Nebraska Medical Center.

9) Interim Guidance for Environmental Infection control in Hospital for Ebola Virus. In: CDC: October 3rd 2014.

〔連絡先：テ598-8577 大阪府泉佐野市りんくう往来北 3-23 りんくう総合医療センター放射線技術科 飯塚明寿 E-mail: aeiizuka@yahoo.co.jp] 
環境感染誌 Vol. 35 no. 1, 2020

\title{
Implementation of a Remotely Controlled FPD System for X-ray Imaging in an Advanced Isolation Room
}

\author{
Akihisa IIZUKA ${ }^{1)}$, Masumi YAmaUCHI ${ }^{2,3)}$, Keiko FukAGAWA ${ }^{2,3)}$ and Masaya Yamato $\left.2,3,4\right)$ \\ ${ }^{1)}$ Department of Radiology, Rinku General Medical Center, ${ }^{2)}$ Department of Infection Control Management, Rinku General Medical Cen- \\ ter, ${ }^{3)}$ Rinku General Medical Center, Center for Infectious Diseases, ${ }^{4)}$ Rinku General Medical Center Division of General Medicine and \\ Infectious Diseases
}

\begin{abstract}
Our medical institution is a designated center for the treatment of patients with infectious diseases such as Ebola virus disease (EVD), which was a major epidemic in West Africa beginning in 2014. We set up an advanced isolation room containing a flat-panel detector (FPD) system that was used for the X-ray imaging of a patient suspected to have EVD. The FPD system appeared to be very useful from the viewpoint of performing early image examinations, obtaining a diagnosis, and preventing the spread of the virus. However, it is very difficult and complicated for staff wearing full personal protective equipment to operate the personal computer (PC) of an FPD system from within the advanced isolation room. Therefore, we constructed a remotecontrol system in which all PC operations of the FPD system could be performed in a separate room, without the need for staff to wear full personal protective equipment. We consider that a remotely controlled FPD system would be advantageous for operating medical equipment in an advanced isolation room, particularly from the viewpoint of infection control.
\end{abstract}

Key words: Institution for Specific Infectious Diseases, advanced isolation ward, X-ray photography, remote-control system for PC of flat-panel detector system 